\title{
PENGARUH PUPUK KANDANG SAPI DAN PUPUK GANDASIL B TERHADAP PERTUMBUHAN DAN HASIL TANAMAN BUNCIS ( Phaseolus vulgaris L ) VARIETAS LEBAT-3
}

\author{
Musdalifah $^{1}$ dan Marisi Napitupulu ${ }^{2}$ \\ ${ }^{1}$ Agroteknologi, Fakultas Pertanian, Universitas 17 Agustus 1945 Samarinda, Indonesia. \\ ${ }^{2}$ Dosen Fakultas Pertanian, Universitas 17 Agustus 1945 Samarinda 75124, Indonesia. \\ E-Mail: musdalifah@untag-smd.ac.id
}

\begin{abstract}
ABSTRAK
Pengaruh Pupuk Kandang Sapi dan Pupuk Gandasil B Terhadap Pertumbuhan dan Hasil Tanaman Buncis (Phaseolus vulgaris L.) Varietas Lebat-3. Tujuan penelitian adalah untuk mengetahui pengaruh pupuk kandang sapi dan pupuk Gandasil B serta interaksinya terhadap pertumbuhan dan hasil tanaman buncis varietas Lebat-3, dan juga untuk mengetahui dosis pupuk kandang sapi dan konsentrasi pupuk Gandasil B yang terbaik bagi pertumbuhan dan hasil tanaman buncis varietas Lebat-3.

Penelitian dilaksanakan selama 4 bulan, terhitung mulai dari bulan Februari 2017 sampai dengan Mei 2017. Lokasi penelitian terletak di Jl. Pendidikan, Kecamatan Sangatta Utara, Kabupaten Kutai Timur.

Penelitian menggunakan analisis faktorial $3 \times 3$ dalam Rancangan Acak Lengkap (RAL), dengan 5 kali ulangan. Faktor penelitian terdiri atas 2 faktor. Faktor I adalah Pupuk Kandang Sapi (K), terdiri atas 3 taraf, yaitu : tanpa pupuk kandang sapi atau kontrol $\left(\mathrm{k}_{0}\right)$, dosis pupuk kandang sapi 10 ton/ha setara $200 \mathrm{~g} / \mathrm{polibag}$ $\left(\mathrm{k}_{1}\right)$, dan dosis pupuk kandang sapi 20 ton/ha setara $400 \mathrm{~g} /$ polibag $\left(\mathrm{k}_{2}\right)$. Faktor II adala Pupuk Gandasil B (B), terdiri atas 3 taraf, yaitu : tanpa pupuk Gandasil B atau kontrol $\left(\mathrm{b}_{0}\right)$, konsentrasi pupuk Gandasil B 2 g/l.air $\left(b_{1}\right)$, dan konsentrasi pupuk Gandasil B 4 g/l.air $\left(b_{2}\right)$.

Perlakuan pupuk kandang sapi tidak berpengaruh nyata terhadap tinggi tanaman umur 20 hari setelah tanam, umur berbunga, panjang polong, jumlah polong per tanaman dan berat polong per tanaman. Berpengaruh sangat nyata terhadap panjang tanaman umur 40 hari setelah tanamlam.
\end{abstract}

Kata kunci : Buncis, Pertumbuhan, Pupuk Gandasil B, Pupuk kandang sapi.

\begin{abstract}
Effect of Cow Manure and Gandasil B Fertilizer on the Growth and Yield of Bean (Phaseolus vulgaris L.), Lebat-3 Variety. The research aimed to study the effect of cow manure and Gandasil B fertilizer and its interaction on the growth and yield of bean, and also to find proper dosage of cow manure and concentration of Gandasil B fertilizer for the best growth and yield of beans.

The research was conducted for 4 months, starting from February 2017 until May 2017. It located on Jl. Pendidikan, Sub district of Sangatta Utara, of East Kutai Regency.The researchused $3 \times 3$ factorial analysis in Completely Randomized Design (RAL), with 5 replications. The first factor was Cow Manure dosage $(K)$, consisting of 3 levels, namely: no cow manure application or control ( $\left.k_{0}\right), 10$ tons/ha equal to $200 \mathrm{~g} /$ polybag $\left(k_{1}\right)$, and 20 tons/ha equal to $400 \mathrm{~g} /$ polybag $\left(k_{2}\right)$. The second factor was Gandasil B Fertilizer (B), consisting of 3 levels, ie no Gandasil B application or control $\left(b_{0}\right), 2 \mathrm{~g} / \mathrm{l}$.water $\left(b_{1}\right)$, and $4 \mathrm{~g} / \mathrm{l}$.water $\left(b_{2}\right)$.

The research results showed that cow manure do not affect significantly on the plant height at age 20 days after planting, age of crop flowered, pod length, number of pods per crop and weight of pod per crop. But it affect very significantly on the plant length at age 40 days after planting.
\end{abstract}

Key words : Bean, Cow Manure, Gandasil B fertilizer, Growth. 


\section{PENDAHULUAN}

Tanaman buncis (Phaseolus vulgaris L.) memiliki manfaat bagi manusia sebagai salah satu sumber gizi bagi kesehatan tubuh manusi Selain bernilai bergizi cukup tinggi, kandungan protein nabati lebih aman dan sehat bila dikonsumsi bagi para vegetarian yang sedang menjalani program diet. Berbagai tanaman kacang-kacangan yang merupakan tanaman sayuran, seperti kacang panjang, buncis, dan kacang polong, terbukti memiliki kandungan serat dan protein yang tinggi bahkan diantaranya cenderung rendah kalori. Kandungan gizi buncis pada tiap $100 \mathrm{~g}$ yaitu : protein 19,8 g, lemak 1,3 g, karbohidrat $65 \mathrm{~g}$, kalsium $90 \mathrm{~g}$, besi 5,6 $\mathrm{mg}$, vitamin B1 0,45 $\mu \mathrm{g}$, vitamin B2 0,21 $\mu \mathrm{g}$, kalori 346 (Sunarjono, 2009 ).

Buncis merupakan tanaman sayuran yang banyak digemari oleh masyarakat Indonesia, karena dapat menyehatkan tubuh karena bernilai gizi tinggi dan dapat dikonsumsi dalam bentuk segar (panen polong muda). Peningkatan produksi tanaman buncis tentu akan memenuhi kebutuhan pasar dalam negeri, terutama pasar tradisional mapun pasar modern (swalayan). Pemberdayaan masyarakat tani dalam rangka peningkatan produksi tanaman buncis merupakan peluang usaha bagi para petani dalam rangka mensejahterakan petani dan keluarganya, seperti adanya kucuran kredit usahatani untuk membantu permodalan dari pemerintah melalui perbankan.

Tanaman buncis merupakan tanaman semusim, pertumbuhannya tergantung pada daya dukung lingkungan yang baik pula, seperti kondisi ekologi tanaman, teutama kondisi lahan terkait dengan kesuburan tanah. Disamping itu juga penerapan teknik bercocok tanam yang baik dengan menerapkan paket teknologi pertanian sesuai anjuran. Upaya perbaikan kesuburan tanah terutama pada tanah marjinal atau tanah yang kurang subur memerlukan pengetahuan yang cukup, terutama bagaimana melakukan pemupukan yang benar, seperti cara memupuk, berapa dosisnya, jenis pupuk yang sesuai dengan kebutuhan tanaman, dan waktu yang tepat untuk memupuk.

Peningkatan produksi tanaman memerlukan input nutrien atau unsur hara pada lahan yang kurang subur atau rendah unsur haranya. Penggunaan pupuk organik, seperti pupuk kandang sapi yang banyak terdapat dipedesaan sangat dianjurkan pada budidaya tanaman buncis, karena dapat memperbaiki sifat fisik, kimia dan biologi tanah, seperti dikemukakan oleh Patanga dan Yuliarti (2016), bahwa penggunaan pupuk organik dapat menyuburkan tanah, memperbaiki struktur tanah dan mempertahankan kesuburan tanah scara terus-menerus.

Selain pupuk organik, perlu pula dilakukan penambahan pupuk cair sebagai suplemen tambahan unsur hara bagi tanaman, seperti pemberian pupuk Gndasil B, yang dapat diaplikasikan melalui penyemprotan lewat daun, cepat diserap oleh tanaman. Pupuk pelengkap cair seperti pupuk daun Gandasil B banyak di jual di toko pertanian di daerah Sangatta, dan banyak dipakai oleh petani untuk meningkatkan produksi tanaman. Menurut Lingga dan Marsono (2009), pupuk Gandasil B merupakan pupuk anorganik yang mengandung unsur hara makro dan mikro, berbentuk serbuk, untuk merangsang pertumbuhan generatif.

Berdasarkan uraian diatas, maka dilakukan penelitian : " Pengaruh Pemberian Pupuk Kandang Sapi dan Pupuk Gandasil B Terhadap Pertumbuhan dan Hasil Tanaman Buncis (Phaseolus vulgaris L.) Varietas Lebat-3. Tujuan Penelitian adalah untuk mengetahui pengaruh pupuk kandang sapi dan pupuk Gandasil B serta 
interaksinya terhadap pertumbuhan dan hasil tanaman buncis varietas Lebat-3. Untuk mengetahui dosis pupuk kandang sapi dan konsentrasi pupuk Gandasil B yang terbaik bagi pertumbuhan dan hasil tanaman buncis varietas Lebat-3.

\section{METODA PENELITIAN}

\subsection{Tempat dan Waktu}

Penelitian dilaksanakan di Jl. Pendidikan, Kecamatan Sangatta Utara, Kabupaten Kutai Timur. Pada bulan Februari-Mei 2017.

\subsection{Bahan dan Alat}

Bahan-bahan yang digunakan dalam penelitian ini adalah: tanah lapisan atas (top soil), benih buncis varietas Lebat-3, pupuk kandang sapi siap pakai, Gandasil B, Furadan 3 G, air sumur untuk menyiram tanaman. Sedangkan alat-alat yang akan digunakan adalah : cangkul, parang, garu, kawat penyaring, timbangan, polibag ukuran $40 \times 50 \mathrm{~cm}$, tali rafia, hand sprayer, turus bambu (ajir) meteran, alat tulis menulis dan kamera, gembor, ember, dan timbangan analitik.

\subsection{Rancangan Percobaan}

Rancangan yang digunakan dalam penelitian ini adalah Rancangan Acak Lengkap (RAL) dengan analisis faktorial $3 \times 3$, dengan ulangan sebanyak 5 kali, terdapat 45 tanaman. Adapun faktor perlakuan tersebut adalah :

Faktor I adalah Dosis Pupuk Kandang Sapi (K), terdiri atas 4 taraf, yaitu :

$\mathrm{k}_{0}=$ tanpa pupuk kandang sapi

$\mathrm{k}_{1}=$ dosis pupuk kandang sapi 10 ton ha ( $200 \mathrm{~g} /$ polibag)

$\mathrm{k}_{2}=$ dosis pupuk kandang sapi 20 ton ha ( $400 \mathrm{~g} /$ polibag)

Faktor II adalah Pupuk Gandasil B (B), terdiri atas 3 taraf, yaitu : $\mathrm{b}_{0}=$ tanpa pupuk Gandasil B (kontrol)

$\mathrm{b}_{1}=$ konsentrasi pupuk Gandasil B $2 \mathrm{~g} / \mathrm{l}$.air

$\mathrm{b}_{2}=$ konsentrasi pupuk Gandasil B 4 g/l.air

Terdapat 3x3 kombinasi perlakuan seperti terlihat di bawah ini :

$\begin{array}{lll}\mathrm{k}_{0} \mathrm{~b}_{0} & \mathrm{k}_{0} \mathrm{~b}_{1} & \mathrm{k}_{0} \mathrm{~b}_{2} \\ \mathrm{k}_{1} \mathrm{~b}_{0} & \mathrm{k}_{1} \mathrm{~b}_{1} & \mathrm{k}_{1} \mathrm{~b}_{2} \\ \mathrm{k}_{2} \mathrm{~b}_{0} & \mathrm{k}_{2} \mathrm{~b}_{1} & \mathrm{k}_{2} \mathrm{~b}_{2}\end{array}$

\subsection{Pelaksanaan Penelitian}

\section{Persiapan Media}

Tanah yang akan dijadikan media tanam untuk penelitian berasal dari tanah lapisan atas dengan kedalaman 0-20 cm, yang ada di sekitar lokasi penelitian. Pertama - tama tanah di cangkul beberapa kali hingga bongkahan tanah menjadi hancur, menjadi berbutir halus dan gembur. Kemudian tanah dibersihkan dari batu, kayu, gulma atau lainnya. Setelah itu tanah dimasukkan ke dalam polibag dengan ukuran $40 \mathrm{~cm}$ x 50 $\mathrm{cm}$, dengan berat tanah setelah ditimbang sekitar $20 \mathrm{~kg}$. Setelah semua polibag terisi dengan tanah, diberi Furadan $3 \mathrm{G}$ dengan dosis $3 \mathrm{~g} /$ polibag, selanjutnya polibag disusun sesuai dengan tata-letak polibag yang telah diacak secara sederhana dengan menggunakan undian, dengan jarak antar polibag $80 \mathrm{~cm}$ x 80 cm (Tabel 1).

\section{Pemberian Pupuk Kandang Sapi}

Pupuk kandang sapi diberikan satu kali, yaitu satu minggu sebelum tanam sesuai dengan dosis perlakluan pada penelitian, yaitu: tanpa pupuk kandang sapi atau kontrol $\left(b_{0}\right)$, dosis pupuk kandang sapi 10 ton/ha setara 200 $\mathrm{g} /$ polibag $\left(\mathrm{b}_{1}\right)$, dan dosis pupuk kandang sapi 20 ton/ha setara $400 \mathrm{~g} /$ polibag $\left(\mathrm{b}_{2}\right)$. Penanaman

Penanaman benih buncis dengan cara ditugal dengan kedalaman $4 \mathrm{~cm}$. 
Dalam satu polibag terdapat satu lubang tanam, tiap lubang diisi benih 2 biji, kemudian lubang tanaman ditutup kembali. Setelah tanaman berumur satu (1) minggu, tanaman dijarangkan dan disisakan hanya satu tanaman tiap polibag.

Pemberian pupuk daun Gandasil B

Pupuk daun Gandasil B diberikan sesuai dosis perlakuan, yaitu : tanpa pupuk daun Gandasil B atau kontrol $\left(\mathrm{b}_{0}\right)$, konsentrasi pupuk daun Gandasil B 2 $\mathrm{g} / \mathrm{l}$.air $\left(\mathrm{b}_{1}\right)$, dan konsentrasi pupuk daun Gandasil B 4 g/l.air $\left(b_{2}\right)$. Pupuk daun Gandasil B diberikan dengan cara menyemprotkan keseluruh bagian tanaman, terutama pada daun bagian atas dan bawah. Pupuk daun Gandasil B diberikan mulai dari pertumbuhan sampai tanaman berbunga pada jam 09.00-10.00 pagi dengan interval penyemprotan 7 hari sekali. Diberikan pada pagi hari, karena pada saat itu stomata pada daun tanaman telah membuka.

\section{Pemeliharaan Tanaman}

Pemeliharaan tanaman meliputi:
a. Penyulaman
Penyulaman dilakukan pada umur 7-10 hari setelah tanam, dengan cara menggunakan tanaman cadangan sesuai dengan perlakuan penelitian.

b. Pemasangan ajir atau turus

Turus dipasang dengan jarak 5 $\mathrm{cm}$ dari tanaman pada umur tanaman 10 hari setelah tanam. Turus tanaman dari bambu dengan tinggi $150 \mathrm{~cm}$

c. Penyiraman

Penyiraman menggunakan air sumur, dilakuakan setiap hari, yaitu pada pagi hari dan sore hari, atau disesuaikan kelembaban tanah apabila turun hujan.

d. Penyiangan
Penyiangan dilakukan setiap saat bila ada gulma yang tumbuh di dalam polibag maupun yang tumbuh diantara barisan polibag secara manual.

\section{Panen}

Panenan pertama buncis dilakukan pada umur tanaman 50 hari setelah tanam. Panen dilakukan 4 kali panen dengan interval waktu 5 hari sekali. Ciriciri panen dalam polong belum menonjol dan permukaan kulitnya agak kasar.

\subsection{Pengamatan dan Pengumpulan Data}

Data yang diambil dalam penelitian ini adalah sebagai berikut:

Panjang Tanaman $(\mathrm{cm})$

Panjang tanaman diukur pada saat tanaman berumur 20 dan 40 hari setelah tanam. Diukur mulai dari pangkal batang yang telah diberi tanda sampai titik tumbuh.

Umur Berbunga (hari)

Waktu berbunga dihitung dengan cara melihat munculnya bunga pertama kali pada tiap-tiap perlakuan.

Panjang Polong $(\mathrm{cm})$

Panjang buah tiap kali panen diukur dengan menggunakan meteran dari masing-masing perlakuan sesuai perlakuan pada setiap kali panen, kemudian dirata-ratakan.

(polong)

Jumlah Polong Per Tanaman

Jumlah buah atau polong dihitung dari mulai panen pertama sampai 4 kali panen dari masing-masing perlakuan.

Berat Polong Per Tanaman (g) 
Berat buah atau polong ditimbang dari masing-masing perlakuan pada setiap kali panen (sebanyak 4 kali panen), kemudian dijumlahkan untuk memperoleh berat polong per tanaman.

\subsection{Analisis Data}

Untuk mengetahui pengaruh perlakuan pupuk kandang sapi dan pupuk daun Gandasil B serta interaksinya, maka dilakukan analisis dengan Sidik Ragam (Uji F) (Steel dan Torrie, 1991).
Apabila hasil sidik ragam tidak berpengaruh nyata, dimana F.Hitung $\leq \mathrm{F}$. Tabel 5\%, maka tidak dilakukan uji lanjut, tetapi bila hasil sidik ragam berpengaruh nyata $(\mathrm{F}$-Hitung $\geq \mathrm{F}$ Tabel 5\%), atau berpengaruh sangat nyata (F-Hitung $\geq$ F-Tabel 1\%), maka untuk membandingkan dua rata-rata perlakuan, dilakukan uji lanjut dengan menggunakan Uji Beda Nyata Terkecil (BNT) pada taraf 5\%.

Rumus Umum Uji BNT disajikan sebagai berikut:

$$
\text { BNT 5\% = t-Tabel (a,db) } x \sqrt{2 \mathrm{KT} \mathrm{Galat} / \mathrm{rt}}
$$

Keterangan :

$\mathrm{t}$-Tabel = Nilai Tabel (sebaran nilai pada t-student a $5 \%$ dengan dbnya)

KT Galat $=$ Kuadrat Tengah Galat

$\mathrm{r} \quad=$ Ulangan

\section{HASIL PENELITIAN DAN PEMBAHASAN}

\subsection{Panjang Tanaman Umur 20 Hari}

Setelah Tanam

Hasil sidik ragam menunjukkan bahwa perlakuan pupuk kandang sapi (K), pupuk Gandasil B (B) dan interaksinya $(\mathrm{KxB})$ tidak berpengaruh nyata terhadap panjang tanaman umur 20 hari setelah tanam (Tabel 1).

\subsection{Panjang Tanaman Umur 40 Hari}

\section{Setelah Tanam}

Hasil sidik ragam menunjukkan bahwa perlakuan pupuk kandang sapi (K) dan pupuk Gandasil B (B) berpengaruh sangat nyata, sedangkan interaksinya $(\mathrm{KxB})$ tidak berpengaruh nyata terhadap panjang tanaman umur 40 hari setelah tanam (Tabe 1)
Hasil uji BNT taraf 5\% terhadap panjang tanaman umur 40 hari setelah tanam pada perlakuan pupuk kandang sapi (K) menunjukkan bahwa perlakuan $\mathrm{k}_{2}$ berbeda nyata dengan perlakuan $\mathrm{k}_{1}$ dan $\mathrm{k}_{0}$. Perlakuan $\mathrm{k}_{1}$ tidak berbeda nyata dengan perlakuan $\mathrm{k}_{0}$.

Hasil uji BNT taraf 5\% terhadap panjang tanaman umur 40 hari setelah tanam pada perlakuan pupuk Gandasil B (B) menunjukkan bahwa perlakuan $b_{2}, b_{1}$ dan $b_{0}$ satu sama lainnya saling berbeda nyata.

\subsection{Umur Berbunga}

Hasil sidik ragam menunjukkan bahwa perlakuan pupuk kandang sapi (K) dan interaksinya $(\mathrm{KxB})$ tidak berpengaruh nyata, sedangkan perlakuan pupuk Gandasil B (B) berpengaruh sangat nyata terhadap umur berbunga (Tabel 1). 
Hasil uji BNT taraf 5\% terhadap panjang tanaman umur 40 hari setelah tanam pada perlakuan pupuk Gandasil B (B) menunjukkan bahwa perlakuan $b_{2}, b_{1}$ dan $b_{0}$ satu sama lainnya saling berbeda nyata.

\subsection{Panjang Polong}

Hasil sidik ragam menunjukkan bahwa perlakuan pupuk kandang sapi (K) dan interaksinya $(\mathrm{KxB})$ tidak berpengaruh nyata, sedangkan perlakuan pupuk Gandasil B (B) berpengaruh sangat nyata terhadap panjang polong (Tabel 1).

Hasil uji BNT taraf 5\% terhadap panjang tanaman umur 40 hari setelah tanam pada perlakuan pupuk Gandasil B (B) menunjukkan bahwa perlakuan $b_{2}, b_{1}$ dan $b_{0}$ satu sama lainnya saling berbeda nyata.

\subsection{Jumlah Polong Per Tanaman}

Hasil sidik ragam menunjukkan bahwa perlakuan pupuk kandang sapi (K) dan interaksinya $(\mathrm{KxB})$ tidak berpengaruh nyata, sedangkan perlakuan pupuk Gandasil B (B) berpengaruh sangat nyata terhadap jumlah polong per tanaman (Tabel 1).

Hasil uji BNT taraf 5\% terhadap panjang tanaman umur 40 hari setelah tanam pada perlakuan pupuk Gandasil B (B) menunjukkan bahwa perlakuan $b_{2}, b_{1}$ dan $b_{0}$ satu sama lainnya saling berbeda nyata.

\subsection{Berat Polong Per Tanaman}

Hasil sidik ragam menunjukkan bahwa perlakuan pupuk kandang sapi (K) dan interaksinya $(\mathrm{KxB})$ tidak berpengaruh nyata, sedangkan perlakuan pupuk Gandasil B (B) berpengaruh sangat nyata terhadap berat polong per tanaman (Tabel 1).

Hasil uji BNT taraf 5\% terhadap panjang tanaman umur 40 hari setelah tanam pada perlakuan pupuk Gandasil B (B) menunjukkan bahwa perlakuan $b_{2}, b_{1}$ dan $b_{0}$ satu sama lainnya saling berbeda nyata.

Tabel 1. Rekapitulasi Data Penelitian Pengaruh Pupuk Kandang Sapi dan Pupuk Gandasil B Terhadap Pertumbuhan dan Hasil Tanaman Buncis (Phaseolus vulgaris L.) Varietas Lebat-3

\begin{tabular}{|c|c|c|c|c|c|c|}
\hline \multirow{2}{*}{ Faktor Perlakuan } & \multicolumn{2}{|c|}{$\begin{array}{l}\text { Panjang Tanaman } \\
(\mathrm{cm})\end{array}$} & \multirow{2}{*}{$\begin{array}{l}\text { Umur } \\
\text { Berbunga } \\
\text { (hari) }\end{array}$} & \multirow{2}{*}{$\begin{array}{l}\text { Panjang } \\
\text { Polong } \\
(\mathrm{cm})\end{array}$} & \multirow{2}{*}{$\begin{array}{c}\text { Jumlah } \\
\text { Polong/ } \\
\text { Tanaman } \\
\text { (polong) }\end{array}$} & \multirow{2}{*}{$\begin{array}{c}\text { Berat } \\
\text { Polong/ } \\
\text { Tanaman } \\
\text { (g) }\end{array}$} \\
\hline & $20 \mathrm{HST}$ & $40 \mathrm{HST}$ & & & & \\
\hline \multicolumn{7}{|l|}{ Pupuk } \\
\hline $\begin{array}{l}\text { Kandang } \\
\text { Sapi }(\mathrm{K})\end{array}$ & $\operatorname{tn}$ & $* *$ & tn & $\operatorname{tn}$ & $\operatorname{tn}$ & $\operatorname{tn}$ \\
\hline \multicolumn{7}{|l|}{ Sidik Ragam } \\
\hline 0 ton//ha $\left(\mathrm{k}_{0}\right)$ & 16,99 & $96,27 \mathrm{~b}$ & 40,00 & 11,27 & 18,97 & 121,80 \\
\hline 10 ton/ha $\left(\mathrm{k}_{1}\right)$ & 17,25 & $100,07 \mathrm{~b}$ & 39,13 & 11,33 & 19,63 & 124,20 \\
\hline 20 ton/ha $\left(\mathrm{k}_{2}\right)$ & 17,47 & $112,00 \mathrm{a}$ & 39,07 & 12,07 & 21,09 & 136,80 \\
\hline $\begin{array}{l}\text { Pupuk Gandasil B } \\
\text { (B) } \\
\text { Sidik Ragam }\end{array}$ & tn & $* *$ & $* *$ & $* *$ & $* *$ & $* *$ \\
\hline $0 \mathrm{ml} / \mathrm{l}$.air $\left(\mathrm{b}_{0}\right)$ & 15,92 & $85,60 \mathrm{c}$ & $42,47 \mathrm{c}$ & $10,40 \mathrm{c}$ & $17,05 \mathrm{c}$ & $108,93 \mathrm{c}$ \\
\hline 2 g/l.air $\left(b_{1}\right)$ & 17,10 & $102,93 \mathrm{~b}$ & $39,13 \mathrm{~b}$ & $11,47 \mathrm{~b}$ & $19,76 \mathrm{~b}$ & $127,13 \mathrm{~b}$ \\
\hline $4 \mathrm{ml} / \mathrm{l}$.air $\left(\mathrm{b}_{2}\right)$ & 18,68 & $119,80 \mathrm{a}$ & $36,60 \mathrm{a}$ & $12,07 \mathrm{a}$ & $22,87 \mathrm{a}$ & $146,73 \mathrm{a}$ \\
\hline $\begin{array}{l}\text { Interaksi }(\mathrm{KxB}) \\
\text { Sidik Ragam }\end{array}$ & $\operatorname{tn}$ & $\operatorname{tn}$ & tn & tn & $\operatorname{tn}$ & $\operatorname{tn}$ \\
\hline
\end{tabular}




\begin{tabular}{lcccccc}
\hline $\mathrm{k}_{0} \mathrm{~b}_{0}$ & 16,06 & 82,80 & 43,20 & 10,00 & 16,00 & 101,20 \\
$\mathrm{k}_{0} \mathrm{~b}_{1}$ & 17,80 & 93,20 & 39,40 & 11,20 & 19,30 & 124,80 \\
$\mathrm{k}_{0} \mathrm{~b}_{2}$ & 17,10 & 112,80 & 37,40 & 12,60 & 21,60 & 139,40 \\
$\mathrm{k}_{1} \mathrm{~b}_{0}$ & 16,10 & 78,80 & 42,00 & 10,40 & 17,60 & 111,80 \\
$\mathrm{k}_{1} \mathrm{~b}_{1}$ & 17,00 & 101,60 & 38,60 & 11,20 & 19,48 & 123,60 \\
$\mathrm{k}_{1} \mathrm{~b}_{2}$ & 18,64 & 119,80 & 36,80 & 12,40 & 21,80 & 137,20 \\
$\mathrm{k}_{2} \mathrm{~b}_{0}$ & 15,60 & 95,20 & 42,20 & 10,80 & 17,56 & 113,80 \\
$\mathrm{k}_{2} \mathrm{~b}_{1}$ & 15,50 & 114,00 & 39,40 & 12,00 & 20,50 & 133,00 \\
$\mathrm{k}_{2} \mathrm{~b}_{2}$ & 20,30 & 126,80 & 35,60 & 13,40 & 25,20 & 163,60 \\
\hline
\end{tabular}

Keterangan :

**: berpengaruh sangat nyata

tn : tidak berpengaruh nyata

HST : Hari Setelah Tanam $\mathrm{k}_{0}$ : tanpa pupuk kandang sapi (kontrol)

$\mathrm{k}_{1}$ : dosis pupuk kandang sapi 10 ton/ha

$\mathrm{k}_{2}$ : dosis pupuk kandang sapi 20 ton/ha

$\mathrm{b}_{0}$ : tanpa pupuk Gandasil B (kontrol)

$\mathrm{b}_{1}$ : konsentrasi pupuk Gandasil B $2 \mathrm{~g} / \mathrm{l}$.air

$\mathrm{b}_{2}$ : konsentrasi pupuk Gandasil B $4 \mathrm{~g} / \mathrm{l}$.air
Pengaruh Pupuk Kandang Sapi Terhadap Pertumbuhan dan Hasil Tanaman Buncis (Phaseolus vulgaris L.) Varietas Lebat-3. Hasil sidik ragam menunjukkan bahwa perlakuan pupuk kandang sapi tidak berpengaruh nyata terhadap panjang tanaman umur 20 hari setelah tanam, umur berbunga, panjang polong, diameter polong, jumlah polong per tanaman dan berat polong per tanaman. Berpengaruh sangat nyata terhadap panjang tanaman umur 40 hari setelah tanam.

Secara umum perlakuan pemberian pupuk kandang sapi tidak berpengaruh nyata terhadap semua parameter pelitian yang diamati. Keadaan ini disebabkan karena kondisi kesuburan tanah di media tanam di polibag tidak sesuia dengan keadaan ideal untuk pertumbuhan tanaman buncis (syarat tumbuh tanaman buncis, yaitu 5,5 - 6,5 (Sunarjono. 2009). Berdasarkan hasil analisis tanah di laboratorium, $\mathrm{pH}$ tanahnya sangat masam $(\mathrm{pH} \mathrm{4,00)}$ dan kejenuhan basa rendah (20,08), dengan demikian tanah dalam keadaan tidak dapat menyediakan unsur hara yang cukup untuk pertumbuhan tanaman, walaupun telah diberikan perlakuan pupuk kandang sapi dengan dosis 20 ton/ha setara 400 g/polibag, karena pupuk kandang sapi mengandung unsur hara NPK sangat sedikit, yaitu $0,40 \% \mathrm{~N}_{2}, 0,20 \mathrm{P}_{2} 0_{5}$ dan $0,10 \% \quad \mathrm{~K}_{2} 0$ (Yuliarti, 2016). Dengan demikian tetap saja masih kekurangan unsur hara karena faktor lingkungan tumbuhnya yang tidak mendukung, karena kondisi tanah yang sangat masam, kondisi ini menyebabkan unsur N, P dan $\mathrm{K}$ sukar larut, dan biasanya terjerab oleh koloid liat dan humus, sehingga tidak tersedia bagi tanaman, sedangkan unsur mikro seperti Al. Fe dan Mn mudah larut, sehingga bila diserap oleh tanaman bisa menyebabkan keracunan pada akar tanaman, karena diserap dalam jumlah banyak. Hal ini sesuai dengan yang dikemukakan oleh Winarso (2010), bahhwa bila kondisi tanah sangat masam, maka bisa menyebabkan pertumbuhan tanaman terhambat, karena kelarutan unsur Al sangat tinggi, bila diserap akar tanaman bisa menyebabkan keracunan. Ditambahkan oleh Sutedjo (2008), bahwa pada $\mathrm{pH}$ tanah antara 5,5-6,5 unsur hara mudah diserap oleh tanaman.

Berdasarkan hasil hasil penelitian perlakuan yang paling baik adalah $\mathrm{k}_{2}$ (pupuk kandang sapi 20 ton/ha) dengan 
jumlah polong 21,09 polong per tanaman dan berat polong 136,80 g/tanaman. Hasil ini masih sangat rendah bila dibandingkan dengan hasil dari deskripsi tanaman kacang buncis Lebat-3, yaitu $1315 \mathrm{~g} /$ tanaman.

Pengaruh Pupuk Gandasil B Terhadap Pertumbuhan dan Hasil Tanaman Buncis (Phaseolus vulgaris L.) Varietas Lebat-3. Hasil sidik ragam menunjukkan bahwa perlakuan pupuk Gandasil B tidak berpengaruh nyata terhadap panjang tanaman umur 20 hari setelah tanam. Berpengaruh sangat nyata terhadap panjang tanaman umur 40 hari setelah tanam, umur berbunga, panjang polong, diameter polong, jumlah polong per tanaman dan berat polong per tanaman.

Hasil sidik ragam menunjukkan bahwa pemberian pupuk Gandasil B berpengaruh tidak nyata terhadap panjang tanaman buncis pada umur 20 hari setelah tanam, hal ini disebabkan bahwa tanaman masih kecil, dan jumlah daun yang terbentuk belum banyak, sehingga pemberin pupuk Gandasil B melalui daun belum dapat diserap dengan maksimal, sehingga belum menunjukkan pengaruh yang nyata.

Hasil sidik ragam menunjukkan bahwa perlakuan pupuk Gandasil B berpengaruh nyata terhadap tinggi tanaman umur 40 hari setelah tanam. Tanaman terpanjang terdapat pada perlakuan $b_{2}$ (konsentrasi pupuk Gandasil B 4 g/l.air), yaitu 119,80 cm, sedangkan tanaman terpendek terdapat pada perlakuan $b_{0}$ (tanpa pupuk Gandasil B atau kontrol), yaitu $85,60 \mathrm{~cm}$. Semakin meningkat konsentrasi pupuk Gandasil B yang diberikan, maka semakin meningkat pula panjang tanaman, dan aplikasi pupuk yang diberikan sudah lima (5) dan juga daun yang terbentuk sudah semakin banyak, sehingga semakin banyak pupuk yang dapat diserap oleh daun. Kondisi ini dapat terjadi karena adanya peranan unsur nitrogen yang terkandung dalam pupuk Gandasil B, yaitu sekitar $6 \%$ (Lingga dan Marsono, 2009), yaitu dapat memacu pertumbuhan tanaman, seperti dikemukakan oleh Munawar (2011), bahawa unsur nitrogen berperan dalam pertumbuhan vegetatif tanaman, seperti batang dan daun.

Hasil sidik ragam nenunjukkan bahwa pupuk Gandasil B berpengaruh sangat nyata terhadap umur berbunga (Tabel 1). Hal ini diduga bahwa dengan pemberian pupuk Gandasil B akan mempengaruhi masa pembungaan tanaman buncis. Sebagaimana dikemukakan oleh Lingga dan Marsono (2009), bahwa pupuk daun Gandasil B merupakan pupuk anorganik yang mengandung unsur hara makro dan mikro, berbentuk serbuk, berguna untuk merangsang pertumbuhan generatif. Salah satu pertumbuhan generatif tanaman adalah keluarnya bunga. Ditambahkan oleh Nyakpa dkk., (1988), bahwa pertumbuhan dan perkembangan tanaman dipengaruhi oleh faktor genetik dan faktor lingkungan.

Hasil sidik ragam nenunjukkan bahwa pupuk Gandasil B berpengaruh sangat nyata terhadap panjang polong, jumlah polong per tanaman dan berat polong per tanaman. Berdasarkan Tabel 1, perlakuan pupuk Gandasil B dengan konsentrasi 4 g/l.air $\left(b_{2}\right)$ memberikan hasil yang lebih baik dibandingkan perlakuan lainnya, yaitu dengan panjang polong 12,07 cm, jumlah polong 21,09 polong/tanaman, dan berat polong 146,73 g/tanaman. Keadaan ini diduga bahwa dengan pemberian pupuk Gandasil B pada konsentrasi 4 g/l.air, akan meningkatkan jumlah unsur hara yang diberikan lewat daun, dengan demikian akan meningkatkan pula jumlah unsur hara yang dapat masuk melalui stomata ke dalam tubuh tanaman. Kelebihan pupuk yang diberikan lewat daun adalah bahwa unsur hara tersebut mudah larut 
dan cepat diserap tanaman (Lingga dan Marsono, 2013). Banyaknya unsur hara yang berasal dari pemberian pupuk Gandasil B yang terakumulasi di dalam tubuh tanaman seperti unsur N, P, K, dan unsur mikro lainnya akan meningkatkan bobot komponen produksi polong kacang buncis, seperti panjang polong, jumlah polong dan berat polong. Peranan dan ketersediaan masing-masing unsur hara tersebut sangat penting dalam mencapai hasil yang diharapkan. Seperti dikemukakan oleh Nyakpa dkk., (1988), unsur nitrogen berperan dalam pembentukan protein dan klorofil, unsur fosfor diperlukan untuk pembentukan buah dan biji, serta unsur kalium berperan dalam sintesa karbohidrat dan dan transfer hasil fotosintesis kebagian tanaman sperti buah dan biji. Pernyataan ini dperkuat oleh Sutedjo (2008), bahwa unsur fosfor mempercepat pemasakan buah dan biji, dan unsur kalium berperan penting dalam pembentukan karbohidrat dan protein.

Pada saat penelitian, keadaan iklim sangat mendukung, rata-rata jumlah curah hujan per bulan dan jumlah hari hujan per bulan pada bulan Februari 225,00 mm dengan jumlah hari hujan 10 hari, pada Maret jumlah curah hujan 263,00 mm dengan jumlah hari hujan 19 hari, dan pada bulan April, jumlah curah hujan 165,00 mm, dengan jumlah hari hujan 10 hari, kondisi ini cukup menguntungkan dalam pemberian pupuk Gandasil B melalui daun, sehingga banyak unsur hara yang dapat diserap oleh tanaman, sehingga akhirnya dapat meningkatkan jumlah polong dan berat polong tanaman buncis per tanaman.

Pengaruh Interaksi Perlakuan Pupuk Kandang Sapi dan Pupuk Gandasil B Terhadap Pertumbuhan dan Hasil Tanaman Buncis (Phaseolus vulgaris L.) Varietas Lebat-3. Hasil sidik ragam menunjukkan bahwa interaksi perlakuan pupuk kandang sapi dan pupuk Gandasi
B tidak berpengaruh nyata terhadap panjang tanaman umur 20 hari dan umur 40 hari setelah tanam, umur berbunga, panjang polong, diameter polong, jumlah polong per tanaman dan berat polong per tanaman.

Berdasarkan hasil sidik ragam interaksi perlakuan pupuk kandang ayam dan pupuk Gandasil B tidak berpengaruh nyata terhadap semua parameter penelitian, seperti panjang tanaman, umur berbunga, panjang polong, jumlah polong dan berat polong per tanaman, keadaan ini disebabkan bahwa pada perlakuan pupuk kandang sapi, pupuk yang diberikan tidak dapat diserap oleh akar tanaman, karena tanahnya dalam keadaan masam ( $\mathrm{pH} 4,00)$ dan keadaan kationkation basa (kejenuhan basa rendah) seperi unsur $\mathrm{Ca}, \mathrm{Ma}, \mathrm{K}$ dan $\mathrm{Na}$ rendah. Sedangkan pemberian pupuk Gandasil B lewat daun juga tidak terjadi interaksi, karena diduga bahwa pupuk yang diberikan konsentrasinya masih rendah, karena dari hasil penelitian belum menunjukkan hasil yang maksimal.

Secara umum interaksi perlakuan antara pupuk kandang sapi dan pupuk Gandasil B tidak memberikan pengaruh yang nyata terhadap panjang tanaman umur $20 \mathrm{HST}$, $40 \mathrm{HST}$, umur berbunga, panjang polong, jumlah polong/tanaman dan berat polong/tanaman. Hal ini disebabkan bahwa masing-masing perlakuan tidak saling berinteraksi dan bertindak bebas satu sama lainnya. Secara umum perlakuan interaksi yang paling baik adalah perlakuan $\mathrm{k}_{2}$ untuk semua parameter penelitian

\section{KESIMPULAN}

Kesimpulan dari hasil penelitian adalah sebagai berikut :

Perlakuan pupuk kandang sapi tidak berpengaruh nyata terhadap tinggi tanaman umur 20 hari setelah tanam, 
umur berbunga, panjang polong, jumlah polong per tanaman dan berat polong per tanaman. Berpengaruh sangat nyata terhadap panjang tanaman umur 40 hari setelah tanam.

Perlakuan pupuk Gandasil B tidak berpengaruh nyata terhadap panjang tanaman umur 20 hari setelah tanam. Berpengaruh sangat nyata terhadap panjang tanaman umur 40 hari setelah tanam, umur berbunga, panjang polong, jumlah polong per tanaman dan berat polong per tanaman. Polong terberat per tanaman terdapat pada perlakuan $b_{2}$ (konsentrasi pupuk Gandasil B 4 g/l.air), yaitu 146,73 g/tanaman, sedangkan berat polong teringan terdapat pada perlakuan $\mathrm{b}_{0}$ (tanpa pupuk Gandasil B atau kontrol), yaitu 108,93 g/tanaman.

Interaksi perlakuan pupuk kandang sapi dan pupuk Gandasi B tidak berpengaruh nyata terhadap panjang tanaman umur 20 hari dan umur 40 hari setelah tanam, umur berbunga, panjang polong, jumlah polong per tanaman dan berat polong per tanaman.

\section{DAFTAR PUSTAKA}

Lingga, P dan Marsono. 2009. Petunjuk Penggunaan Pupuk. Jakarta: Penebar Swadaya.

Lingga, P. dan Marsono. 2013. Petunjuk Penggunaan Pupuk. Jakarta: Penebar Swadaya.
Munawar, A. 2011. Kesuburan Tanah dan Nutrisi Tanaman. Bogor: IPB Press.

Nyakpa, M.Y, Lubis A.M, Pulung M.A, Amrah A.G, Munawar A, Hong G.B dan akim N. 1988. Kesuburan Tanah. Lampung: Universitas Lampung.

Steel, R.G.D. dan Torrie, J.H. 1991. Prinsip dan Prosedur Statistika Suatu Pendekatan Biometrik. Jakarta: Gramedia.

Sunarjono, H. 2009. Bertanam 30 Jenis Sayuran. Jakarta: Penebar Swadaya.

Sutedjo, M, M. 2008. Pupuk dan Cara Pemupukan. Jakarta: Rineka Cipta.

Winarso, S. 2010. Kesuburan Tanah, Dasar

Kesehatan dan Kualitas

Tanah. Yogyakarta:

Gava Media.

Yuliarti, N. 2016. Cara Menghasilkan Pupuk Organik. Yogyakarta: Lily Publisher. 